\title{
Therapeutic Evaluation of Levofloxacin and Lugol's Iodine for Subclinical Endometritis
}

\author{
Arshaq Asfar ${ }^{1 *}$, Khursheed A. Sofi ${ }^{2}$, Aaliya Fayaz ${ }^{3}$, Mudasir A. Bhat ${ }^{4}$, Mehrajuddin Naikoo ${ }^{1}$ and \\ Sanober Rasool ${ }^{5}$ \\ ${ }^{1}$ Division of Animal Reproduction, Gynaecology and Obstetrics, Sher-e-Kashmir University of Agricultural Sciences and \\ Technology of Kashmir, JEK, INDIA \\ ${ }^{2}$ Division of Veterinary Clinical Complex Sher-e-Kashmir University of Agricultural Sciences and Technology of Kashmir, \\ JEK INDIA \\ ${ }^{3}$ Division of Livestock Production and Management Sher-e-Kashmir University of Agricultural Sciences and Technology of \\ Kashmir, JEK INDIA \\ ${ }^{4}$ Division of Animal Nutrition Sher-e-Kashmir University of Agricultural Sciences and Technology of Kashmir, JEK, INDIA \\ ${ }^{5}$ Division of Veterinary and Animal Husbandry Extension, Sher-e-Kashmir University of Agricultural Sciences and \\ Technology of Kashmir, JEK, INDIA \\ "Corresponding author: A. Asfar; E-mail: arshaqasfar@gmail.com
}

Received: 07 June, 2020

Revised: 27 July, 2020

Accepted: 31 July, 2020

\begin{abstract}
Study was conducted in cross-bred cows ( $>60$ days-in-milk) to evaluate various therapeutic regimens for Subclinical Endometritis (SCE). A total of 60 animals tested positive for SCE by Endometrial Cytology (EC) were divided into five groups with equal number. Therapeutic regimens viz. 0.3\% Lugol's iodine I/U (G-I), Lenovo-AP I/U (G-II), Meriflox I/M (G-III), Meriflox I/M + AI (G-IV) and No treatment + AI as control (G-V), each treatment opted for 3 days. In G-I, II and III, Whiteside test (WST) of Estrual Mucus and Artificial Insemination (AI) was done on subsequent estrus to evaluate recovery and conception rates, respectively. However, in G-IV and G-V, AI was performed on concurrent estrus to evaluate conception rate. Treatment efficacy was analyzed by recovery rate based on negative WST at next estrus (G-I, II, III) and conception rate evaluated based on pregnancy diagnosis after two months of AI in all groups. Group-I, II and III revealed recovery rate of $83.3 \%, 50 \%$ and $100 \%$ as well as conception rate of $50 \%, 50 \%$ and $66.7 \%$, respectively. However, no difference was found in conception rate of G-IV (33.3\%) and G-V i.e. control (33.3\%). Further, treatment cost calculated per animal was ₹-9 for Lugol's iodine, ₹-135 for Lenovo-AP and ₹-230 for Meriflox. In conclusion, Meriflox (Levofloxacin) by intramuscular route and AI on subsequent estrus can be recommended for treatment of SCE, and to improve conception rate. Apart from being economical, Lugol's iodine laden with enormous benefits can be advocated as alternative treatment option via intrauterine administration for SCE.
\end{abstract}

\section{HIGHLIGHTS}

(0 Efficacy of Lugol's iodine compared with antibiotic as it has numerous advantages.

0 Effective treatment option was found to be Levofloxacin.

(- Lugol's iodine was slightly less effective but the most economical treatment option.

Keywords: Subclinical endometritis, Endometrial cytology, AI, conception, Levofloxacin, Lugol's iodine

Subclinical endometritis (SCE) is inflammation of the internal lining of uterus (endometrium) in the dearth of quantifiable signs of endometritis, which causes considerable decline of reproductive performance (Sheldon et al., 2009). It is also called cytological endometritis and is associated with an amplified percentage (proportion) of polymorphonuclear cells (PMN) in samples of endometrial cytology (Kasimanickam et al., 2004).

How to cite this article: Asfar, A., Sofi, K.A., Fayaz, A., Bhat, M.A. Naikoo, M. and Rasool, S. (2020). Therapeutic evaluation of levofloxacin and lugol's iodine for subclinical endometritis. J. Anim. Res., 10(4): 623627.

Source of Support: None; Conflict of Interest: None क क 
Regarding the treatment of SCE, there is no evidencebased, valid single recommendation for therapy of SCE (Wagener et al., 2017) as described by few studies on treatment strategies. Currently, in the literature quite a few controversial reports are available regarding the effectiveness of treatment protocols for SCE, i.e. Cephapirin (Kasimanickam et al., 2005; Denis-Robichaud and Dubuc, 2015), PGF2 $\alpha$ (Lima et al., 2013), Ceftiofur (Dubuc et al., 2011), combination of LevofloxacinOrnidazole and $\alpha$-Tocopherol (Markandeya et al., 2010), Lugol's iodine (Sood et al., 2012; Ahmed and Elsheikh, 2014), Moxifloxacin (Purohit et al., 2013), NSAIDs (Priest et al., 2013), Oxytetracycline (Singh et al., 2014), Levofloxacin (Kumar et al., 2017) and many more.

Uterine bacterial culture sensitivity test has shown Fluoroquinolone group as highly sensitive antibiotic group (Malinowski et al., 2011; Purohit et al., 2013; Sharma et al., 2017). However, the preferred treatment should not be limited to clinical or microbiological cure but should improve the fertility along with economical consideration. Use of antibiotics to combat uterine infections results in variable success and often requires milk disposal due to fear of residual antibiotics in milk. Apart from high cost of treatment, there are also chances of development of antibiotic resistance. Conversely, Lugol's iodine has no withdrawal period which is truly advantageous and except in excess administration it does not penetrate into the milk (Carleton et al., 2008) besides having antifungal, antiprotozoal and even antiviral properties in addition to its antibacterial properties (Sekhon, 2012) and intra-uterine infusion of diluted Lugol's iodine significantly reduces the rate of services per conception and mean length of days open (Ahmed and Elsheikh, 2014).

\section{MATERIALS AND METHODS}

This investigation was carried out at Veterinary Clinical Complex (VCC), FVSc \& AH, Shuhama, Srinagar and Mountain Livestock Research Institute (MLRI), Manasbal, Ganderbal. Screening was done in crossbred postpartum cows of $>60$ DIM that were presented for AI at VCC and MLRI. The main criteria's for screening were no apparent clinical signs of any disease, clear estrual mucus discharge and without any gross reproductive tract pathology as examined per-rectally. All the cows were in age group of 3-12 years with $73.3 \%$ cows falling in age group of 3-5 years. Similarly, parity was ranging from 1-7 parities with $63.3 \%$ cows falling in parity range of $1-2$ parities.

Sixty (60) animals were diagnosed positive for SCE by EC using Cytobrush with $\geq 4 \%$ PMNs as cut-off value as per Singh et al. (2016). EM from study animals was collected at 6 to $12 \mathrm{hr}$ after the onset of oestrus as described by Bhat et al., 2014 with slight modification. All the positive animals were divided into five treatment groups of 12 animals each (Table 1).

Table 1: Different treatment regimens followed in the study

\begin{tabular}{|c|c|}
\hline $\begin{array}{l}\text { Group } \\
(\mathrm{N}=60)\end{array}$ & Treatment regimen followed \\
\hline $\mathrm{I}(\mathrm{n}=12)$ & $\begin{array}{l}0.3 \% \text { Lugol's Iodine @ } 30 \mathrm{ml} \mathrm{I} / \mathrm{U} \times 3 \text { Days + WST } \\
\text { and AI on next heat }\end{array}$ \\
\hline $\mathrm{II}(\mathrm{n}=12)$ & $\begin{array}{l}\text { Lenovo AP@30ml I/U × } 3 \text { Days + WST and AI on } \\
\text { next heat }\end{array}$ \\
\hline III $(n=12)$ & $\begin{array}{l}\text { Meriflox @ } 4-5 \mathrm{mg} / \mathrm{kg} \text { body weight I/M } \times 3 \text { Days }+ \\
\text { WST and AI on next heat }\end{array}$ \\
\hline $\operatorname{IV}(n=12)$ & $\begin{array}{l}\text { Meriflox @ } 4-5 \mathrm{mg} / \mathrm{kg} \text { body weight } \mathrm{I} / \mathrm{M} \times 3 \text { Days }+ \\
\mathrm{AI} \text { at the same heat }\end{array}$ \\
\hline$V(n=12)$ & Control Group, AI + NO Treatment \\
\hline
\end{tabular}

$\mathrm{N}=$ total number of animals; $\mathrm{n}=$ number of animals in one group.

\section{Group-I (n=12)}

Intra-uterine administration of $30 \mathrm{ml}$ of $0.3 \%$ lugol's iodine once a day for three days was carried out in this group. Lugol's iodine $(0.3 \%)$ solution was prepared fresh from 5\% stock solution of lugol's iodine (Sisco Research Laboratories Pvt. Ltd., India) and final volume was made with distilled water. On the next estrus, EM was again collected from the treated cows, subjected to WST and then artificially inseminated with proven good quality frozen semen deposited in body of uterus. AI was performed after $12 \mathrm{hrs}$ of onset of estrus in all the study animals by the same veterinarian.

\section{Group-II (n=12)}

In this group, $30 \mathrm{ml}$ of Lenovo AP (Intas Pharmaceuticals Ltd, India) which contains levofloxacin $(20 \mathrm{mg} / \mathrm{ml})$, ornidazole $(40 \mathrm{mg} / \mathrm{ml})$ and alpha-tocopherol $(5 \mathrm{mg} / \mathrm{ml})$ was administered by intra-uterine route once a day for three days. On the next estrus, EM was collected and 
subjected to WST and the cows were then artificially inseminated as in group-I.

Group-III ( $\mathrm{n}=12)$

Meriflox (Vetoquinol India Animal Health Pvt. Ltd., India) which contains levofloxacin $(100 \mathrm{mg} / \mathrm{ml})$ was given at a dose rate of 4-5 $\mathrm{mg}$ per $\mathrm{kg}$ body weight by intra-muscular route once a day for 3 days. On the next estrus EM was collected and subjected to WST and the cows were artificially inseminated as in group-I.

\section{Group-IV (n=12)}

Along the treatment with Meriflox (4-5 mg/kg body weight) by intra-muscular route once a day for three days, the cows were also artificially inseminated as in group-I at the same estrus.

\section{Group-V (n=12)}

The animals in this group were kept as control without treatment but were artificially inseminated as in group-I at the same estrus.

Evaluation of efficacy of treatment regimen of Group I, II and III was evaluated based on WST at next estrus and conception rate while for Group IV, was evaluated only on conception rate in comparison to Group V (Control). Assessment of conception rate in all the groups was made by pregnancy diagnosis (PD) after 50-60 days of AI by rectal palpation.

\section{RESULTS AND DISCUSSION}

In group-I, $83.3 \%$ animals showed recovery based on negative WST and conception rate of $50 \%$ was found based on pregnancy diagnosis after 2 months of AI. Similarly, in group-II, both the recovery and conception rates were found to be $50 \%$. However, in group-III, in which Meriflox was given intramuscularly for three days, $100 \%$ animals showed recovery and conception rate of $66.7 \%$ was detected.

In group-IV, the conception rate was found to be $33.3 \%$. In group- $\mathrm{V}$ i.e control, in which only insemination was done without any treatment, the conception rate was also found to be $33.3 \%$ (Table 2 ).
Table 2: Recovery rate and conception rate in different treatment groups $(\mathrm{N}=60)$

\begin{tabular}{|c|c|c|c|}
\hline $\begin{array}{l}\text { Group } \\
\text { No }\end{array}$ & Treatment & $\begin{array}{c}\text { Recovery } \\
\text { rate (-ve } \\
\text { WST) }\end{array}$ & $\begin{array}{l}\text { Conception } \\
\text { rate }\end{array}$ \\
\hline $\begin{array}{l}\mathrm{I} \\
(\mathrm{n}=12)\end{array}$ & $\begin{array}{l}\text { Lugol's Iodine }(0.3 \% \times 30 \mathrm{ml} \times \\
\mathrm{I} / \mathrm{U} \times \mathrm{OD} \times 3 \text { days })\end{array}$ & $83.3 \%$ & $50.0 \%$ \\
\hline $\begin{array}{l}\text { II } \\
(n=12)\end{array}$ & $\begin{array}{l}\text { Lenovo } \mathrm{AP}(30 \mathrm{ml} \times \mathrm{I} / \mathrm{U} \times \mathrm{OD} \\
\times 3 \text { days })\end{array}$ & $50.0 \%$ & $50.0 \%$ \\
\hline $\begin{array}{l}\mathrm{III} \\
(\mathrm{n}=12)\end{array}$ & $\begin{array}{l}\text { Meriflox }(4-5 \mathrm{mg} / \mathrm{kg} \text { bw } \times \mathrm{I} / \mathrm{M} \\
\times \mathrm{OD} \times 3 \text { days })\end{array}$ & $100 \%$ & $66.7 \%$ \\
\hline $\begin{array}{l}\text { IV } \\
(n=12)\end{array}$ & $\begin{array}{l}\mathrm{AI}+\text { Meriflox }(4-5 \mathrm{mg} / \mathrm{kg} \text { bw } \times \\
\mathrm{I} / \mathrm{M} \times \mathrm{OD} \times 3 \text { days })\end{array}$ & $*$ & $33.3 \%$ \\
\hline $\begin{array}{l}\mathrm{V} \\
(\mathrm{n}=12)\end{array}$ & $\mathrm{AI}+\mathrm{No}$ treatment (Control) & $*$ & $33.3 \%$ \\
\hline
\end{tabular}

$\mathrm{N}=$ total number of animals; $\mathrm{n}=$ number of animals in one group.

\section{Economy of treatment}

When comparing the treatment cost per animal, Lugol's iodine was found to be cost effective with only nine rupees approx (₹ 09) treatment cost per animal while Meriflox treatment came out to be much expensive at ₹ 230 approx per animal. For the third treatment regime opted in which Lenovo AP was used, cost of treatment per animal remained in between the former treatments at ₹ 135 approx (Table 3).

Table 3: Economics of treatment per animal and milk withdrawal period comparison

\begin{tabular}{|c|c|c|c|c|}
\hline $\begin{array}{l}\text { Treatment } \\
\text { option }\end{array}$ & $\begin{array}{l}\text { Amount } \\
\text { used/ } \\
\text { animal }\end{array}$ & Cost /unit & $\begin{array}{c}\text { Approx } \\
\text { Cost / } \\
\text { animal (₹) }\end{array}$ & $\begin{array}{c}\text { Milk } \\
\text { Withdrawal } \\
\text { period }\end{array}$ \\
\hline $\begin{array}{l}\text { Lugol's } \\
\text { iodine }\end{array}$ & $\begin{array}{l}90 \mathrm{ml} \text { of } \\
0.3 \%\end{array}$ & $\begin{array}{l}\text { ₹ } 182 / 125 \mathrm{ml} \\
(5 \%)\end{array}$ & 09 & 0 days \\
\hline Lenovo AP & $90 \mathrm{ml}$ & $₹ 45 / 30 \mathrm{ml}$ & 135 & 7 days \\
\hline Meriflox & $\begin{array}{l}\text { 30ml } \\
\text { Approx }\end{array}$ & ₹ $115 / 15 \mathrm{ml}$ & 230 & 7 days \\
\hline
\end{tabular}

Fluoroquinolones (intramuscular as well as intrauterine) and Lugol's iodine (intrauterine) have been previously used with variable efficacy. The present study revealed that Group-III treated with Meriflox (Levofloxacin) administered I/M for three days with $\mathrm{AI}$ at next estrus showed best results in terms of recovery rate which was $100 \%$ (negative WST) and conception rate $(66.7 \%)$ 
in comparison to other treatment regimens. However, Groups-I \& II treated with $0.3 \%$ Lugol's iodine, I/U for three days and Lenovo AP (Levofloxacin, Ornidazole and alpha-tocopherol) I/U for three days respectively, showed comparable results in terms of conception rate although more number of animals $(83.3 \%)$ recovered (negative WST) when treated with Lugol's iodine as compared to Lenovo AP (50\%). Further, no difference was found in terms of conception rate between Group IV treated with Meriflox (Levofloxacin), I/M for three days after AI and Group-V (Control) where it was $33.3 \%$ in both cases which is far less than other groups.

G-I, in which Lugol's iodine (I/U) was given, showed recovery rate of $83.3 \%$ and conception rate of $50 \%$ which was similar to the results reported by Singh et al. (2018) with recovery rate of $87.50 \%$ and conception rate of $42.86 \%$ but poor results were reported by Sood et al. (2012) and, Sharma and Singh, (2012) in comparison to present study. Sood et al. (2012) reported recovery rate of $56.2 \%$ which could be due to use of treatment for only one day and also diagnostic method used was CFU/ml of EM while Sharma and Singh, (2012) reported recovery rate of $58.3 \%$, which could be due to use of low concentration of Lugol's iodine $(0.1 \%)$ and post treatment presence of fungal growth in uterine discharge was used as diagnostic criteria.

G-II, in which Lenovo AP (I/U) was given, showed recovery rate of $50 \%$ and conception rate of $50 \%$. Similar conception rate of $56.5 \%$ was reported by Bhattacharyya et al. (2011) along with a higher recovery rate of $78.3 \%$ which could be due to treatment regimen followed for five days. Markandeya et al. (2010) reported recovery rate of $77.78 \%$ and conception rate of $66.67 \%$, both higher than the present investigation and could be due to use of double dose of $60 \mathrm{ml}$ of Lenovo AP (I/U). Likewise, elevated recovery rate and conception rate $(86.7 \%$ and $80 \%$ respectively) was reported by Purohit et al. (2013), which could be due to use of high dose rate of $2000 \mathrm{mg}$ Moxifloxacin in comparison to $600 \mathrm{mg}$ of Levofloxacin in the present study. Singh et al. (2018) reported higher recovery rate of $87.9 \%$ but conception rate of $48.3 \%$ coinciding with the present study.

G-III, in which Meriflox I/M was administered, showed recovery rate of $100 \%$ and conception rate of $66.7 \%$ which was in close concurrence with the results reported by Pillai, (2012) and Singh et al. (2018). In another study, Pillai, (2012), reported 100\% recovery rate and $57.9 \%$ conception rate whereas Singh et al. (2018), reported recovery rate of $95.20 \%$ with slightly lower conception rate $(50 \%)$.

G-IV, in which Meriflox I/M was administered in addition to $\mathrm{AI}$ at the same estrus revealed conception rate of $33.3 \%$ which was similar to the control group. To the best of our knowledge there is no published research available in relation to this treatment regimen.

G-V, i.e. control in which AI was performed without any treatment, exhibited conception rate of $33.3 \%$ which was mediocre as compared to other treatment groups. Poorer conception rates of $25 \%$ and $20 \%$ were reported by Singh et al. (2014) and Singh et al. (2018), respectively in untreated control group.

The comparision of results showed Levofloxacin as best treatment for improving recovery as well as conception rate but use of Lugol's iodine also came up with comparable results and it has got other benefits like being lot more economical, has zero withdrawal period, has anti-bacterial, anti-viral, anti-fungal and anti-protozoal properties (Carleton et al., 2008; Sekhon, 2012).

\section{CONCLUSION}

Administration of Meriflox (Levofloxacin) parentally with $\mathrm{AI}$ on subsequent estrus can be recommended for treatment of SCE and improving conception rate. Apart from being economical, Lugol's iodine laden with enormous benefits can be advocated as an alternative treatment option via intrauterine administration for SCE.

\section{ACKNOWLEDGEMENTS}

All the authors are thankful to all those who helped in successful completion of this investigation at MLRI Manasbal and FVSc \& AH, Shuhama, Srinagar, J\&K, INDIA.

\section{Funding}

This research did not receive any specific grant from funding agencies in the public, commercial, or not-forprofit sectors. There are no benefits in any form from a commercial party or any of the authors related directly or indirectly to the subject of this manuscript. 


\section{REFERENCES}

Ahmed, F.O. and Elsheikh, A.S. 2014. Treatment of repeat breeding in dairy cows with lugol's iodine. IOSR J. Agric. Vet. Sci., 7(4): 22-26.

Bhat, F.A., Bhattacharyya, H.K. and Hussain, S.A. 2014. White side test: A simple and rapid test for evaluation of nonspecific bacterial genital infections of repeat breeding cattle. Vet. Res. Forum., 5(3): 177-180.

Bhattacharyya, H.K., Makhdoomi, D.M., Hafiz, A. and Fazili, M.R. 2011. Clinico-therapeutic management of sub-clinical metritis in cows. Intas polivet., 12(1): 26-27.

Carleton, C.L., Threlfall, W.R. and Schwarze, R.A. 2008. Iodine in milk and Serum following intrauterine infusion of Lugol's solution. Int. J. Appl. Res. Vet. Med., 6: 121-129.

Denis-Robichaud, J. and Dubuc, J. 2015. Randomized clinical trial of intrauterine cephapirin infusion in dairy cows for the treatment of purulent vaginal discharge and cytological endometritis. J. Dairy Sci., 98(10):6856-6864.

Dubuc, J., Duffield, T.F., Leslie, K.E., Walton, J.S., and LeBlanc, S.J., 2011. Randomized clinical trial of antibiotic and prostaglandin treatments for uterine health and reproductive performance in dairy cows. J. Dairy Sci., 94: 1325-1338.

Kasimanickam, R., Duffield, T.F., Foster, R.A., Gartley, C.J., Leslie, K.E., Walton, J.S. and Johnson, W.H. 2004. Endometrial cytology and ultrasonography for the detection of subclinical endometritis in postpartum dairy cows. Theriogenology., 62: 9-23.

Kasimanickam, R., Duffield, T.F., Foster, R.A., Gartley, C.J., Leslie, K.E., Walton, J.S. and Johnson, W.H. 2005b. The effect of a single administration of cephapirin or cloprostenol on the reproductive performance of dairy cows with subclinical endometritis. Theriogenology., 63: 818-830.

Kumar, A., Srivastava, S., Yadav, S.K., Yadav, A.K., Saurabh and Chaudhary, V. 2017. Physico-chemical characteristics of cervical discharge in endometritic repeat breeder cow. Int. J. Pure. Appl. Biosci., 5(3): 821-831.

Lima, F.S., Bisinotto, R.S., Ribeiro, E.S., Greco, L.F., Ayres, H., Favoreto, M.G., Carvalho, M.R., Galvao, K.N. and Santos, J.E.P. 2013b. Effects of 1 or 2 treatments with prostaglandin F2 on subclinical endometritis and fertility in lactating dairy cows inseminated by timed artificial insemination. J. Dairy Sci., 96: 6480-6488.

Malinowski, E., Lassa, H., Markiewicz, H., Kaptur, M., Nadolny, M., Niewitecki, W. and Ziętara, J. 2011. Sensitivity to antibiotics of Arcanobacterium pyogenes and Escherichia coli from the uteri of cows with metritis/endometritis. Vet. J., 187(2): 234-238.

Markandeya, N.M., Patil, A.D., Moregaonkar, S.D. and Bhonsle, A.V. 2010. Efficacy of fluoroquinolone in combination with alpha tocopherol to resolve non-specific infections of reproductive tract of dairy animals. Intas Polivet., 11(1): 7-10.

Pillai, V.V. 2012. Efficacy of simultaneous use of enrofloxacin and metronidazole in the treatment of endometritis in crossbred cattle-a field trial. J. Ind. Vet. Assoc., 10(2): 37-39.

Priest, N.V., McDougall, S., Burke, C.R., Roche, J.R., Mitchell, M., McLeod, K.L., Greenwood, S.L. and Meier, S. 2013. The responsiveness of subclinical endometritis to a nonsteroidal antiinflammatory drug in pasture-grazed dairy cows. J. Dairy Sci., 96(7): 4323-4332.

Purohit, G.N., Dholpuria, S., Yadav, S., Barolia, Y. and Kumar, P. 2013. Diagnosis and Treatment of Clinical and Subclinical Endometritis-A Clinical Study in 30 Cows. Intas Polivet., 14(1): 31-33.

Sekhon, B.S. 2012. Iodine: A support against infections and emerging as an antibiotic. J. Pharm. Educ. Res., 3(1): 35-39.

Sharma, A., Singh, M., Kumar, P., Sharma, A., Kashyap, A., Neelam, I.B., Sharma, A., Chaudhary, N. and Sharma, P. 2017. Bacterial Isolation, Culture Sensitivity Test, Endometrial Cytology of Postpartum Cows and Assessment of their Reproductive Performance. Int. J. Curr. Microbiol. Appl. Sci., 6(9): 519-527.

Sharma, S. and Singh, M. 2012. Mycotic Endometritis in Cows and its Therapeutic management. Intas Polivet., 13(1): 29-30.

Sheldon, I.M., Cronin, J., Goetze, L., Donofrio, G. and Schuberth, H.J. 2009. Defining postpartum uterine disease and the mechanisms of infection and immunity in the female reproductive tract in cattle. Biol. Reprod., 81: 1025-1032.

Singh, J., Honparkhe, M., Chandra, M., Kumar, A., Ghuman, S.P.S. and Dhindsa, S.S. 2016. Diagnostic efficacy of uterine cytobrush technique for subclinical endometritis in crossbred dairy cattle. Indian Vet. J., 93(02): 11-13.

Singh, K.P., Singh, B., Singh, S.V., Singh, J.P., Singh, P. and Singh H.N. 2014. Comparative evaluation of anti-microbials in treatment and improving conception rate in endometritic crossbred cows. Intas Polivet., 15(1): 79-82.

Singh, M., Sharma, A., Kumar, P., Bhardwaj, N., Sharma, A. and Bala, I. 2018. Studies on clinical efficacy of some therapeutic regimens for the management of endometritis in cows. Explor. Anim. Med. Res., 8(1): 110-112.

Sood, P., Thakur, S.D., Sarvesh., Dogra, V., Vasishta, N.K., Singh, M.M. and Gandhotra, V.K. 2012. Evaluation of efficacy, intrauterine safety and storage conditions of Lugol's Iodine. Ind. J. Anim. Reprod., 33(1): 71-73.

Wagener, K., Gabler, C. and Drillich, M. 2017. A review of the ongoing discussion about definition, diagnosis and pathomechanism of subclinical endometritis in dairy cows. Theriogenology., 94: 21-30. 
